\author{
Daria Rutkowska-Siuda \\ Uniwersytet Łódzki \\ Wydziat Filozoficzno-Historyczny \\ Instytut Historii Sztuki \\ daria.rutkowska-siuda@uni.lodz.pl
}

\title{
Od wiejskiej osady do przemysłowego miasta Historia i rozwój urbanistyczny Stąporkowa od XVIII w. do lat sześćdziesiątych XX w.
}

„Stąporków, wieś, folwark i zakłady żelazne nad rzeką Czarną"” - taki wstęp w opisie Stownika geograficznego Królestwa Polskiego i innych krajów stowiańskich wymienia koordynaty identyfikujące ten ośrodek w XIX wieku. Historia mieszkańców i rozwój osady były ściśle związane z funkcjonowaniem w przestrzeni wiejskiej czynnika miastotwórczego - przemysłu, tutaj hutniczego i górniczego. Cykl pracy wyznaczały zasiewy i żniwa oraz rozpalanie i wygaszanie wielkiego pieca.

Stąporków obecnie jest miastem położonym w województwie świętokrzyskim, w powiecie koneckim². Tereny Kielecczyzny zaliczane są do tzw. Staropolskiego Zagłębia Przemysłowego. Obszary te niegdyś obfitowały w złoża surowców mineralnych, np.: rud żelaza, hematytu, syderytu, siarki, cynku, miedzi, piaskowca, marmuru. Tutejsza ludność wykorzystywała środowisko naturalne oraz złoża rud metali, stawiała dymarki, kuźnice - poruszane siłą kół wodnych. Do naszych czasów pozostałościami po tej działalności są warpy, zwałowiska

$1 \quad$ Stownik geograficzny Królestwa Polskiego i innych krajów słowiańskich, red. F. Sulimierski, B. Chlebowski, W. Walewski, t. 11, nakładem W. Walewskiego, Warszawa 1883, s. 307.

2 Jako samodzielna jednostka powiat konecki, część departamentu radomskiego, został powołany do życia w 1809 r. w okresie funkcjonowania Księstwa Warszawskiego. Od 1816 r. zaliczany był do województwa sandomierskiego, obwodu opoczyńskiego, z główną siedzibą w Radomiu. W latach 1845-1867 obszar wchodził w skład powiatu opoczyńskiego, guberni radomskiej, od 1918 r. do 1939 r. zaś województwa kieleckiego; R. Wojewódzki, Najważniejsze zabytki techniki powiatu koneckiego, [w:] Tradycje przemystowe ziemi koneckiej. Materialy przygotowane na sesję naukowa, Końskie, 4-5 października 1991, red. W. Różański, Wydawca Towarzystwo Przyjaciół Górnictwa Hutnictwa i Przemysłu Staropolskiego w Kielcach, Zarząd Miejski Naczelnej Organizacji Technicznej w Końskich, Kielce 1991, s. 51. 
oraz hałdy żużlu wielkopiecowego ${ }^{3}$. Do intensywnego rozwoju przemysłu przyczyniła się nie tylko zasobność w rudy metali, lecz także środowisko przyrodnicze. Budowa zakładów wielkopiecowych była ściśle powiązana $z$ występowaniem obszarów leśnych dostarczających drzewa szczepowego, węgla drzewnego (z czasem zastąpionego węglem kamiennym) oraz rzek - w przypadku terenów koneckich: Czarna i Krasna - napędzających maszyny ${ }^{4}$. „Każde większe dominium, a były to obszary wielkich majątków leśnych, starało się o budowę wielkiego pieca. Tak się tworzyły ośrodki leśno-górnicze, jak np. Niekłań, Chlewiska, Bliżyn, Końskie [...]”5.

Wybrany przedział czasowy analizy obejmuje okres od wybudowania w 1738/39 r. pierwszego wielkiego pieca w dobrach koneckich aż do 1967 r., kiedy to Stąporków uzyskał prawa miejskie.

Na przestrzeni dwóch stuleci rozwinął się i ukształtował zasadniczy układ urbanistyczny miejscowości. Historia rozwoju zakładów przemysłowych i górniczych oddziaływała bezpośrednio na ten proces. Specyfika produkcji zakładów, współzależnych od siebie i od zaplecza geologiczno-naturalnego regionu, wpłynęła na tożsamość lokalną. Praca kolejnych pokoleń w zakładach przemysłowych kształtowała warstwę robotniczą, która ciągle nie rezygnowała z pracy rolniczej i hodowli. Ta dychotomia działań pozwalała w zmieniającej się sytuacji społeczno-politycznej od XIX w. do lat 60. XX w., przetrwać ośrodkowi i dynamicznie rozwijać się w II poł. tegoż stulecia.

W niniejszym artykule przeanalizowane zostaną głównie zakłady odlewnicze, mające dominujący wpływ na proces urbanizacji miasta. Do tego celu posłużą materiały zebrane w zasobach: Archiwum Akt Nowych w Warszawie, Archiwum Państwowym w Kielcach, dokumenty i zdjęcia zgromadzone w Miejskiej Bibliotece w Stąporkowie oraz nieliczne publikacje podejmujące problematykę historii, zarówno miasta, jak i późniejszej Odlewni Żeliwa Stąporków. Do najważniejszych dokumentów należy zaliczyć Akta dóbr ziemskich hipoteki powiatu koneckiego Końskie Wielkie, Akta dóbr ziemskich hipoteki powiatu koneckiego Staporków 1909-1932 [1941] oraz książkę Józefa Osińskiego. Istotnymi publikacjami są prace Andrzeja Fajkosza, Tadeusza Szymańskiego - zajmujących się historią zakładów w Stąporkowie ${ }^{6}$. Publikacje Mieczysława Radwana, Czesława Podrzuckiego i Czesława Kalaty, obejmują dużo szersze zagadnienia poświęcone wielkopiecownictwu oraz Staropolskiemu Zagłębiu Przemysłowemu. Istotnym

3 A. Fajkosz, Kartki z historii ziemi koneckiej, Wydawnictwo Muzeum Regionalne PTTK, Kielce Agencja JP, Kielce-Końskie 2010, s. 42.

4 W. Różański, Rozwój odlewnictwa żeliwnego na ziemi koneckiej, [w:] Tradycje przemystowe ziemi koneckiej..., s. 41.

5 Cyt. za: M. Radwan, Wielkopiecownictwo w Zagłębiu Staropolskim w połowie XIX wieku, Wydawnictwo Państwowe Wydawnictwo Techniczne, Stalinogród 1954, s. 23.

6 Dużym mankamentem publikacji wymienionych autorów jest brak podawania źródeł informacji zamieszczonych w tekstach. 
źródłem informacji są również katalogi zakładu, zdjęcia archiwalne - głównie dokumentacja fotograficzna autorstwa Zenona Mączyńskiego ${ }^{7}$, artykuły prasowe oraz wywiad z Wacławą Zarzycką, byłym pracownikiem Zjednoczenia Budownictwa Mieszkaniowego w Radomiu.

\section{Początki istnienia osady}

Nazwa miejscowości Stąporków pochodzi prawdopodobnie od narzędzia stosowanego do kruszenia rudy - stąpora ${ }^{8}$. Pierwsze wzmianki o przemysłowym wykorzystaniu tego obszaru pochodzą z 1577 r. gdzie wymienia się kuźnice, m.in. Stampor ${ }^{9}$. W 1663 r. istniała jeszcze ona na tym terenie. Prawdopodobnie przy kuźnicy mogły znajdować się osoby zatrudnione do jej obsługi. Ziemie te należały pierwotnie do rodu Odrowążów, z czasem przeszły na rodzinę Szczawińskich, a w poł. XVIII w. zostały zakupione przez Jana Małachowskiego ${ }^{10}$, który w dobrach koneckich wybudował szereg pieców do wytopu żelaza, fryszerek ${ }^{11}$. Pierwszy wielki piec hutniczy wzniesiony został przez kanclerza w Stąporkowie $1738 / 1739^{12}$ z pięcioma fryszerkami i Topornią ${ }^{13}$. Do jego obsługi zostali sprowadzeni specjaliści ze Śląska ${ }^{14}$. Do własności kanclerza zaliczały się również piece: w Kuźnicy (1750 r.), dwa w Janowie (1755 r.), w Rudzie Białaczowskiej (1762 r., budowę dokończyła jego żona Izabela z Humieckich Małachowska) oraz wybudowany po jego śmierci, w Antoninie (1780-1781 r. $)^{15}$. W sumie tereny

7 Marian Zenon Mączyński (2.02.1935-8.11.1999) - wieloletni pracownik Odlewni Żeliwa Stąporków, fotograf. Dzięki zdjęciom jego autorstwa, znajdującym się w archiwum rodzinnym Ireny Mączyńskiej, możliwe było prześledzenie zmian w strukturze miejskiej osady. Zgromadzone fotografie dokumentują historię miejscowości od końca lat 40. do lat 90. XX w. Zenon Mączyński fotografował większość uroczystości, wnętrza hal odlewniczych, pracowników zakładu, plakaty, wyroby odlewnicze oraz wszystkie inwestycje budowlane na terenie miasta. Przy dużych brakach archiwaliów powiązanych z historią miasta zbiory Mączyńskich stanowią istotne źródło informacji.

8 M. Radwan, dz. cyt., s. 47.

9 T. Szymański, 250 lat staporkowskich odlewni, „Przegląd Odlewnictwa” 1989, nr 4, s. 117; A. Fajkosz, Tradycje przemysłowe Staporkowa. Rozwój przemystu na terenie Staporkowa i jego okolic od końca XV wieku do roku 1945, [w:] Wczoraj i dziś staporkowskich odlewni, red. tegoż, Wydawca Odlewnia Żeliwa Stąporków im. Rewolucji 1905 r., Stąporków 1978, s. 5.

10 Anonim, Przemystowe tradycje Staporkowa (I), „Odlewnik” 1978, nr 8 (102), s. 3.

11 A. Fajkosz, Kartki z historii..., s. 44. Fryszerka jest to zakład, w którym materiał uzyskany $\mathrm{z}$ wielkich pieców (surówka) był przetapiany na stal w procesie odwęglania.

12 C. Podrzucki, C. Kalata, Metalurgia i odlewnictwo żeliwa, Wydawnictwo Śląsk, Bytom 1971, s. 23.

13 J. Osiński, Opisanie polskich żelaza fabryk..., Drukarnia J.K. Mci i Rzeczypospolitey u XX. Scholarum Piarum, Warszawa 1782, s. 56. Autor podaje rok 1739.

14 A. Fajkosz, Kartki z historii..., s. 48.

15 J. Piwek, Górnictwo i hutnictwo w dobrach białaczowskich Małachowskich w XIX wieku, [w:] Tradycje przemystowe ziemi koneckiej..., s. 33. 
ziemi koneckiej dostarczały ok. $40 \%$ produkcji surówki całego Staropolskiego Zagłębia Przemysłowego ${ }^{16}$. Żelazo pozyskiwane w regionie znajdywało nabywców w Gdańsku, Zamościu oraz w Warszawie, gdzie wysyłana była znaczna część wyprodukowanego metalu.

Budowa zakładów znacząco wpłynęła na rozwój okolicznego rzemiosła. Pobliskie wsie: Koprusa, Stąporków, Wąsosz, Błotnica, Duraczów, Janów, Czarna, Piasek i Smarków specjalizowały się w wyrobie produktów z żelaza, np. gwoździ, kos, siekier ${ }^{17}$.

Kolejnym bodźcem do rozwoju było wprowadzenie taryfy celnej w 1868 r., co skutkowało dynamicznym rozwojem odlewnictwa żeliwnego na terenie Królestwa Polskiego ${ }^{18}$. Fabryki koneckie sprzedawały wyroby żelazne przeważnie do Piotrkowa i Warszawy ${ }^{19}$. Dzięki wybudowaniu w 1885 r. linii kolejowej Iwanogrodzko-Dąbrowskiej, biegnącej z Koluszek do Ostrowca przez Końskie, otwarte zostały rynki zbytu dla towarów produkowanych w lokalnych fabrykach. Pobudziło to w znacznym stopniu gospodarkę i skutkowało powstawaniem licznych, mniejszych zakładów odlewniczych ${ }^{20}$. Oparta na żelazie, produkcja przemysłowa powiatu koneckiego na przełomie XIX i XX w. była najwyższa w guberni radomskiej $^{21}$.

Huta w Stąporkowie do wytopu sprowadzała rudę z Kobylej Góry (między Stąporkowem i Błotnicą) 22 , z góry Osicowa (pod Stąporkowem) oraz ze Starej Góry ${ }^{23}$. Niewiele wiadomo o wyglądzie samej huty oraz produkowanym przez nią asortymencie. Ciekawa jest relacja Józefa Osińskiego z opisania płatności stąporkowskiego majstra piecowego. Pokazuje ona nie tylko dochody, ale również wymienia różne grupy pracowników zatrudnionych przy zakładzie:

„Mayster Piecowy, od Pieca Stąporkowskiego bierze na tydzień złotych 16; oprócz tego przy skończonym roku bierze gratyfikacyi złotych 100; siana fur 6; piwa beczek od garcy 72 , sześć; owsa korcy 12 , nakoniec ma wolne pomięszkanie, ogrody, pola i łąki. Mayster Pieca Stąporkowskiego zawiaduie piecami zwanemi Ruski brod, Ruda, Królewiec, i Antoninów (ostatnie dwa należą do JW. Hyacynta Małachowskiego Podkanclerzego Koronnego) od każdego z tych pieców bierze na tydzień po złotych 12; w położoną płacę nie wchodzi lanie naczyń, za lanie bowiem osobną ma nagrodę, a tę dosyć znaczną, bo ieżeli się nie leni,

$\overline{16}$ J. Osiński, $d z$. cyt., s. 42. W całym kraju funkcjonowały wówczas 34 piece, z czego 12 na ziemi koneckiej.

17 A. Fajkosz, Zaczęło się od wielkiego pieca (Z historii Staporkowa), „Odlewnik” 1980, nr 6 (136), s. 4.

18 Tamże, s. 45.

19 Słownik geograficzny Królestwa Polskiego i innych krajów stowiańskich, red. F. Sulimierski, B. Chlebowski, W. Walewski, t. 4, Warszawa 1883, s. 354.

20 A. Fajkosz, Kartki z historii..., s. 47.

21 Wielka encyklopedia powszechna ilustrowana, t. 37-38, O. Kolberg, Wydawca S. Sikorski, Warszawa 1905, s. 836.

22 J. Osiński, $d z$. cyt., s. 31.

23 Tamże, s. 32. 
i we wszystkich piecach leie, na rok może zyskać około 5000. złotych; zebrawszy tygodniową płacę od 5 pieców, o której wyżej mówiło się, i dodawszy ią do płacy od lania, pokazuie się, iż na rok może wysłużyć i zarobić około 8000 złotych. Ta suma jest znaczna, a zatym niemaiących pewnego sposobu do życia, powinnaby zachęcić do uczenia się tak zyskowney wiadomości. Smelcerz iedem na tydzień bierze złotych 6 , Gichciarz złotych 4, tłuczący żuzel złotych 4 1/2; przy piecu iest dwóch Smelcerzów, Gichciarzów trzech, tyleż tłuczących żuzel, albo Tłuczarzów"24.

Interesującym opisem zakładu w Stąporkowie jest raport Redena i Steina - Prusaków, którzy zwiedzali go w 1781 r. Według ich relacji piec stąporkowski dawał ok. 120-150 cetnarów surówki - co na owe czasy stanowiło wysoki stopień produkcji ${ }^{25}$. Podróżnicy chwalili zakład w Stąporkowie, porównując go do huty Ozimek na Śląsku.

Okres lat 1895-1915 przyniósł obniżenie produkcji w zakładach zaliczanych do klucza dóbr koneckich. Stanisław Małachowski zapisał w testamencie hutę synowi Henrykowi, który od 1855 r. przekazał ją w dziesięcioletnią dzierżawę Harszowi Muhlradowi i Zyslowi Wiślickiemu. W ramach umowy najemcy mogli kontrolować zakłady w Stąporkowie i osiem okolicznych fryszerek. W skład dóbr zaliczały się również mieszkania wzniesione dla pracujących w fabryce, grunty orne oraz pańszczyzna i czynsze od gwoździarzy z osiemnastu pobliskich wsi ${ }^{26}$.

W 1871 r. tereny i hutę kupił Jan Tarnowski. Zakład w 1879 r. zmodernizowano. Wybudowano drugi piec opalany koksem, zainstalowano maszynę parową. Następne prace poczyniono w 1889 r., dzięki czemu zakład produkował ok. 11 ton na dobę. W 1885 r. doprowadzona została do zakładu linia kolejowa. W 1889 r. wzniesiono nowy wielki piec, również opalany koksem ${ }^{27}$. W latach 1886-1900 huta w Stąporkowie była największym prywatnym zakładem funkcjonującym na terenie Królestwa Polskiego. Zatrudniała ona ok. 800 pracowników i produkowała rocznie ok. 4100 ton. Odlewnia posiadała szeroki asortyment towarów, w tym części urządzeń centralnego ogrzewania, piecyki, odlewy piecowe. Grzejniki dekoracyjne przeznaczone były na eksport do Cesarstwa Rosyjskiego ${ }^{28}$. Z 1904/1905 pochodzi plan z hipoteki dóbr Końskie Wielkie przedstawiający „Stemporków”29. Widoczne są wyraźnie zaznaczone obszary zajmowane przez zakład i wielki piec na linii północ-południe (ryc. 1). Obszar ten był podstawą do rozwoju urbanistycznego osady w XIX w. Trakty komunikacyjne rozwijały się w kierunku zachodnim do najbliższego terenu miejskiego - Końskich. Widoczny jest również rozwój w kierunku południowo-zachodnim na drodze prowadzącej

24 Tamże, s. 56-57.

25 A. Fajkosz, Kartki z historii..., s. 48.

26 Tenże, Tradycje przemystowe..., s. 11-12.

27 Tamże, s. 13.

28 T. Szymański, dz. cyt., s. 118.

29 Archiwum Państwowe w Kielcach (dalej: APK), Akta dóbr ziemskich hipoteki powiatu koneckiego, Końskie Wielkie 1880-1911, sygn. 19, s. 771; taka pisownia miejscowości występuje na planie. 
do wsi Czarna i uzdrowiska Czarniecka Góra. Uczęszczaną drogą była szosa prowadząca na Odrowąż, rozciągająca się ku wschodowi. Z miejscowością tą osadników stąporkowskich łączyła diecezja i kościół, do którego parafii należeli.

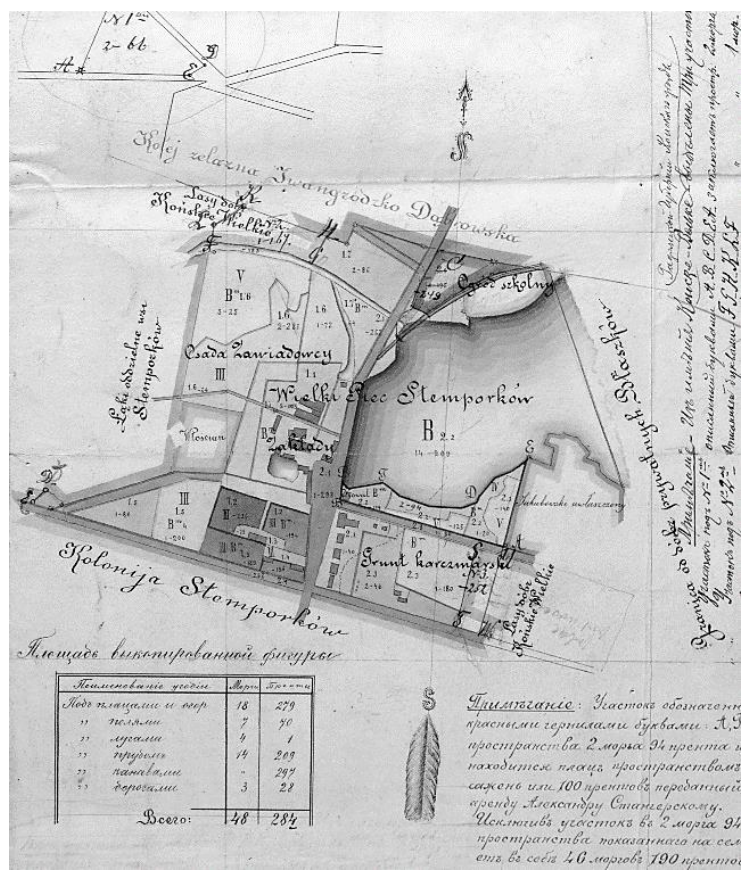

Ryc. 1. Kopia cyfrowa ze zbiorów Archiwum Państwowe w Kielcach, Akta dóbr ziemskich hipoteki powiatu koneckiego, Końskie Wielkie 1880-1911, sygn. 19 , s. 771

W 1910 r. zakłady zakupili i zmodernizowali bracia Lillpopp z Warszawy ${ }^{30}$. Firma nazywała się „Towarzystwo Akcyjne Zakładów Górniczo-Hutniczych i Fabryk Stąporków". W 1925 r. został sporządzony plan zakładu dołączony do dokumentów hipotecznych ${ }^{31}$. Zakład posiadał: halę odlewniczą, pucernie, skład

$\overline{30}$ A. Fajkosz, Z kart historii..., s. 48.

31 APK, Akta dóbr ziemskich hipoteki powiatu koneckiego Stąporków 1909-1932 [1941], sygn. 45, Plan sytuacyjny Nieruchomości stanowiqcych własność „T-wa AKC Zakładów Górniczo-Hutniczych Staporków” w Stąorkowie, hip. „Osada fabryczna Staporków”, pow. gruntów w/g planu geom. wynosi 294807 mtr kw., s. 171. Tamże, Wyszczególnienie i opis budowli, znajdujących się na nieruchomości hipotecznej „Osada fabryczna Staporków” w Staporkowie, stanowiącej własność firmy Towarzystwo Akcyjne Zakładów Górniczo-Hutniczych „Staporków” w Warszawie, sporzadzone przez Towarzystwo Kredytowe Przemystu Polskiego, s. 172-176. Tamże, Wykaz i szacunki maszyn i urzadzeń przemystowych znajdujących się w nieruchomości hipotecznej „Osada fabryczna Staporków” w Sta- 
wyrobów i modeli, modelarnię i kuźnię, biura techniczne, halę maszynową, pocztę i posterunek policji, stodołę ze stajnią, wozownię, piekarnię, budynki mieszkalne i ambulatorium (ryc. 2). Budynki funkcyjne zakładów przeznaczone na potrzeby pracowników - mieszkańców, obejmowały również szkołę zlokalizowaną w jednym z budynków fabryki, działającą z przerwami od $1897 \mathrm{r}$. do lat czterdziestych XX w. Na terenie osady znajdowała się przed I wojną światową Spółdzielnia Spożywcza „Pożytek”, straż pożarna oraz w okresie międzywojennym dwie biblioteki: Polskiej Macierzy Szkolnej i Spółdzielni Spożywczej ${ }^{32}$. W 1932 r. zakłady zostały zlicytowane za długi (niespłacenie zaciągniętych pożyczek w kwocie 18500 funtów szterlingów) zaciągnięte w Towarzystwie Kredytowym Przemysłu Polskiego ${ }^{33}$. Sprzęty, urządzenia fabryczne w dzierżawę wziął inż. Lucjan Kałudzki, zatrudniając również pracujących w Stąporkowie odlewników, formierzy i rzemieślników. Zakłady przeniósł do „Odlewni i Warsztatów Mechanicznych Nieborów" (w późniejszych latach zakład ten stanowił część Zakładów Odlewni Stąporków) ${ }^{34}$. Z 1935 r. pochodzi katalog prezentujący część asortymentu, głównie elementy żeliwne do pieców kaflowych i narzędzia gospodarcze oraz naczynia. Zakłady zostały zamknięte w 1938 r., a ich zabudowania w większości uległy zniszczeniu w wyniku działań wojennych.

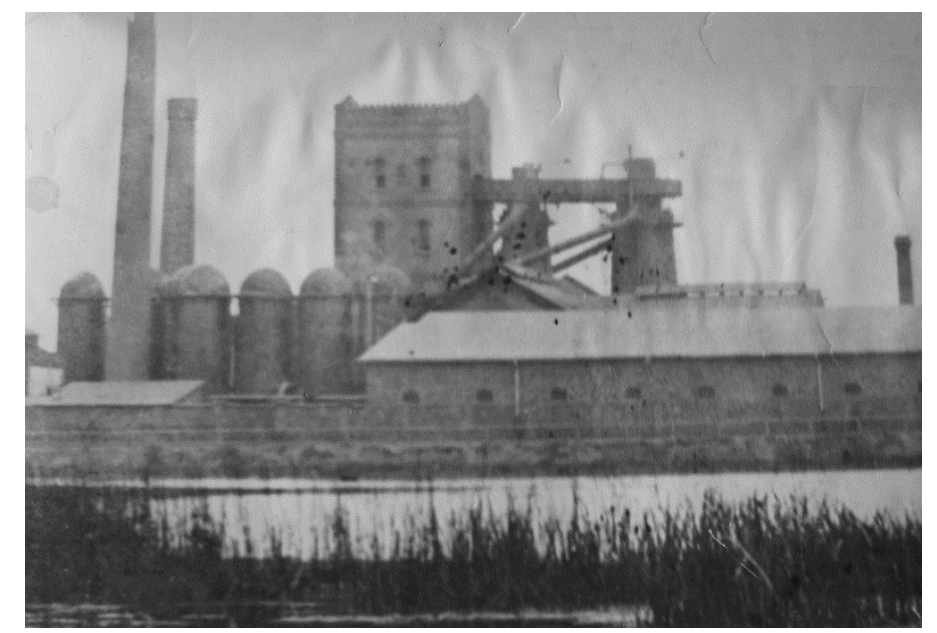

Ryc. 2. Miejsko-Gminny Ośrodek Kultury i Sportu, zbiory Biblioteki w Stąporkowie, Huta Staporków, fot. ok. 1929 r.

porkowie stanowiaca własność firmy Towarzystwo Akcyjne Zakładów Górniczo-Hutniczych „Staporków” w Warszawie, sporządzone przez Towarzystwo Kredytowe Przemystu Polskiego, s. 177-182.

32 A. Fajkosz, Z kart historii: Staporków, „Tygodnik Konecki” 1997, nr 24, s. 11.

33

Zawiadomienie, „Gazeta Warszawska” 1932, s. 9.

34 T. Szymański, dz. cyt., s. 118. 


\section{Przemiany i rozwój ośrodka po II wojnie światowej}

Zakłady zaczęły się odradzać w połowie lat 40 . XX w., początkowo pod nazwą Niekłańskie Zakłady Odlewnicze, w których skład wchodził Stąporków. Stefan Dajczer, jeden z kierujących zakładem od 1945 r., wspomina następująco początki odbudowy zakładów i miejscowości: „Wiele w pierwszych dniach było problemów. Było nas wtedy jeszcze niewielu, lecz za wszelką cenę pragnęliśmy uruchomić produkcję. Była to jedyna szansa poprawienia warunków życia naszych współtowarzyszy. [...] Już w końcu stycznia rozpoczęliśmy działalność produkcyjną. Początkowo produkowaliśmy odlewy rolnicze i kuchenne. Za nie od okolicznych rolników załoga otrzymywała produkty żywnościowe" ${ }^{35}$.

Produkcja zakładu w pierwszych latach powojennych pokrywała głównie zapotrzebowanie na narzędzia i urządzenia rolnicze oraz gospodarstwa domowego: kieraty, młocarki, narzędzia kuchenne, piecyki. Zaopatrywali się w nie rolnicy nie tylko z rejonu Kielecczyzny, lecz także z terenów Sandomierza i Radomia. Gotowe produkty odlewnicze były również wymieniane na artykuły spożywcze. Przedsiębiorstwo zorganizowało podział produktów między pracowników, otworzyło stołówkę przyzakładową ${ }^{36}$.

W 1947 r. wybudowana została hala odlewnicza i produkcję wznowiono. W 1948 r. doszło do połączenia odlewni w Nieborowie i Wołowie, powstało samodzielne przedsiębiorstwo pod nazwą: Odlewnia Żeliwa Niekłań w Stąporkowie. W strukturze firmy odlewnia w Wołowie była wydziałem P-1, w Nieborowie P-2. Nawiązując do tradycji stąporkowskich odlewnia P-1 zajęła się produkcją grzejników c.o. Do terenu Stąporkowa sukcesywnie wcielano kolejne mniejsze wsie, jak: Koprusa, Miła, Sadykierz, Nieborów i Wołów. Nowymi wyznacznikami definiującymi rozwój osady po II wojnie światowej stały się zakłady odlewnicze i kopalnie rozwijające się ku wschodowi. Zaczął uwidaczniać się podział między „starym” i „nowym” Stąporkowem.

W 1952 r. przedsiębiorstwa w porozumieniu z Ministerstwem Budownictwa Miast i Osiedli, Zarządem Budowy Miast i Osiedli ZOR przystąpiły do planów budowy osiedla robotniczego dla pracowników Odlewni Żeliwa Niekłań w Stąporkowie (Plac Wolności) oraz dla pracowników Kopalni Rudy Żelaza „Edward” (osiedle S. Żeromskiego). Oba osiedla planowane były w niedalekiej odległości od zakładów. Między dwoma strefami mieszkaniowymi rozbudowywała się część socjalno-usługowa. Pierwsze bloki były wznoszone z cegły, otynkowane, jednolub dwupiętrowe (ryc. 3). Budynki ogrzewane były na piece - dopiero w końcu lat 60. ukończono budowę kotłowni. Przy Osiedlu Plac Wolności budowanym

\footnotetext{
35 Cyt. za: O. Witkowski, W ludowej Ojczyźnie, [w:] Wczoraj i dziś staporkowskich odlewni, red. A. Fajkosz, Wydawca Odlewnia Żeliwa Stąporków im. Rewolucji 1905 r., Stąporków 1978, s. 62-63.

36 Tamże, s. 63.
} 
w latach 1952-55 powstało przedszkole oraz sklepy ${ }^{37}$. Budowę osiedla tak wspomina Wacława Zarzycka, pracownik Zjednoczenia Budownictwa Miejskiego w Radomiu, oddelegowana do nadzoru nad pracami: „Wszystkie materiały były sprowadzane z Radomia, z cegielni Sołtyków. Ze Zjednoczenia dostawaliśmy pule materiałów do wykorzystania. Odlewnia dużo w tym też pomagała, dawała grzejniki, ale wtedy nie było kotłowni, były piece. Zakłady dostarczały swoich fachowców, jak brakowało nam, to z odlewni przychodziła grupa. [...] Albo budowa, albo odlewnia - sezonowo. Jak było lato - to budowa, jak zima - to roboty wykończeniowe. [...] Przeważnie mieszkania były dwupokojowe z kuchnią. Trzy pokoje to był wyjątek. [...] Na budowę przywoziło się ludzi ze wsi. Nie było rękawic, gumowych butów, jak dostaliśmy ochronną odzież od deszczu to mieli, ale nie wszyscy. A wynagrodzenie też nie było za wysokie, trochę z rolnictwa trochę z odlewni[...]. To miało powstać miasteczko w państwie komunistycznym, bez kościoła, bez cmentarza" ${ }^{\natural 8}$.

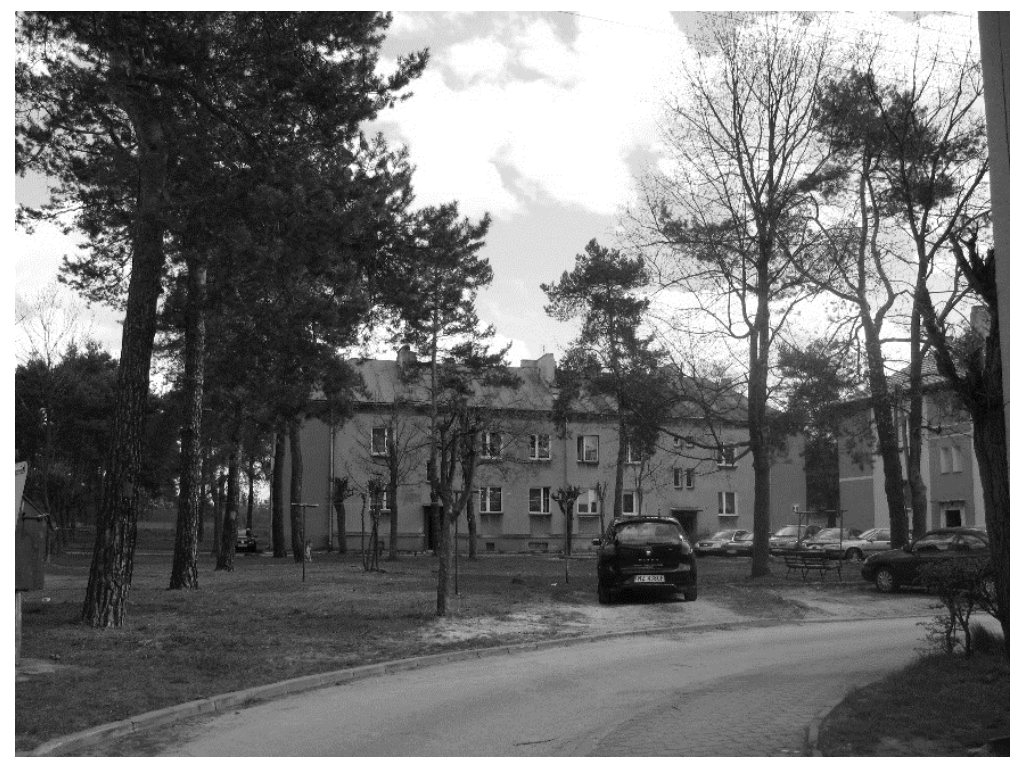

Ryc. 3. Osiedle Plac Wolności, fot. autora, 2014 r.

Osiedle Plac Wolności miało stać się według rozpisanych planów trzonem przyszłego miasta na 5000 mieszkańców, dlatego w jego strukturach zaprojektowano zarówno przestrzeń mieszkalną, jak i strefę wypoczynkową oraz usługową.

37 Zob. Archiwum Akt Nowych (dalej: AAN), Osiedle Stąporków, pow. konecki [Budowa] Założenia [Decyzje, protokoły, korespondencja, notatka protokolanta], 1952-1954, sygn. 2/331/0/4.1/1870.

38 Wywiad z Wacława Zarzycka przeprowadzony 10 maja 2014 r.w Staporkowie, zapis w archiwum autorki. 
Zakładano powstanie: trzech przedszkoli, szkoły zawodowej, jadłodajni, restauracji, ośrodka sportowego i domu kultury. Pierwotne szerokie założenia zostały w Warszawie znacząco zredukowane, tak, aby osiedle tworzyło zamkniętą i zwartą całośćc ${ }^{39}$.

Odlewnia była głównym przedsiębiorstwem inwestującym w rozwój osady. Większość pracowników przyjeżdżała z okolicznych wsi, część przenosiła się do mieszkań zakładowych. Większość z nich nie porzucała jednak swoich gospodarstw. Jak wspomina W. Zarzycka: „Dużo ludzi ze wsi przyszło pracować w odlewni, ale jak pozostawiali gospodarstwo, to popołudniu jechali, utrzymywali pola. [...] Pola były uprawiane, ludzie nawet na czas żniw i wykopków dostawali urlopy" ${ }^{\prime \prime}$.

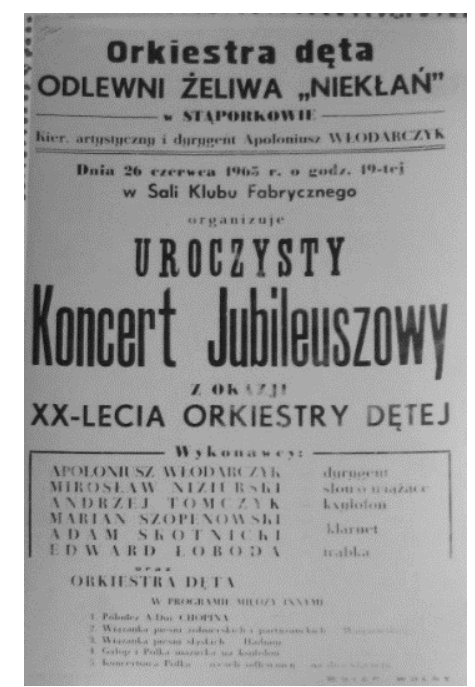

Ryc. 4. Plakat, Uroczysty Koncert Jubileuszowy z okazji XX-lecia Orkiestry Dętej,

fot. Z. Mączyński, 1965 r., zbiory prywatne

Zakłady przemysłowe organizowały życie kulturalno-społeczne swoim pracownikom i ich rodzinom. Odlewnia Żeliwa powołała Międzyzakładowy Dom Kultury. Jak wspomina Pani Zarzycka: „Odlewnia dla młodzieży organizowała wieczorki, koncerty, przedstawienia, spotkania muzyczne. Była orkiestra w odlewni (ryc. 4). Jeżeli ktoś z pracowników chciał się kształcić, zakład wspierał ich, wysyłając na szkolenia, do szkół. Mieszkania dla pracowników były darmowe.

39 AAN, Osiedle Stąporków, pow. konecki [Budowa] Założenia [Decyzje, protokoły, korespondencja, notatka protokolanta], 1952-1954, sygn. 2/331/0/4.1/1870, Koreferat dla KOPI PKPG z dn. 22.IV.1952 r. w sprawie perspektywicznych zatożen projektowych os. Staporków, s. 2.

Wywiad z Wactawa Zarzycka... 
Organizowane były również wczasy dla pracowników i ich rodzin"41. Huta funkcjonowała na trzy zmiany. Pracownicy byli przywożeni z pobliskich wsi autobusami specjalnie do tego celu wynajętymi. Przy zakładzie kwitło życie kulturalne.

Według wspomnień $\mathrm{W}$. Zarzyckiej osada w początku lat 50 . XX w. wyglądała jak: „wieś z kilkoma chatkami drewnianymi. Stąporków był Nowy i Stary. Stary był tam jak teraz jest ul. 1 Maja. Od kościoła do Szkoły nr 2 był Nowy Stąporków, natomiast Wołów był tam gdzie Plac Wolności; ul. Kościuszki to był Sadykierz, Nieborów - z zakładem. Domu kultury nie było tylko młodnik - młode sadzonki świerków" ${ }^{42}$. Z powyższego opisu jasno wynika podział miejscowości między dawny trzon osady, gdzie przed II wojną światową znajdowała się pierwsza huta, a terenem na wschód od niego, biegnącym liniowo, wzdłuż traktu w kierunku Odrowąża, ograniczonych zasięgiem do zakładów rozbudowujących się na terenie Nieborowa i Wołowa. Pomiędzy tymi terenami stopniowo tworzyły się sfery mieszkaniowe, usługowe i kulturowe. Miejscowość traciła stopniowo od lat 60. swój „,wiejski”" charakter z zabudową drewnianą na rzecz budynków murowanych, a w kolejnych dekadach - osiedli z wielkiej płyty (ryc. 5, ryc. 6). W omawianym okresie nie ukształtowało się wyraźne centrum. W pierwotnym planie osiedla robotniczego, które miało stać się podstawą dla nowego miasta, taka przestrzeń została wyraźnie zaznaczona. Po redukcji projektu wdrożonego do realizacji, część ta została ograniczona i nie mogła w przyszłości pełnić funkcji centrum. Dominantami, wokół których kształtowała się siatka urbanistyczna, były zakłady odlewnicze, od których ulice rozchodziły się w układzie przypominającym grzebieniowy.

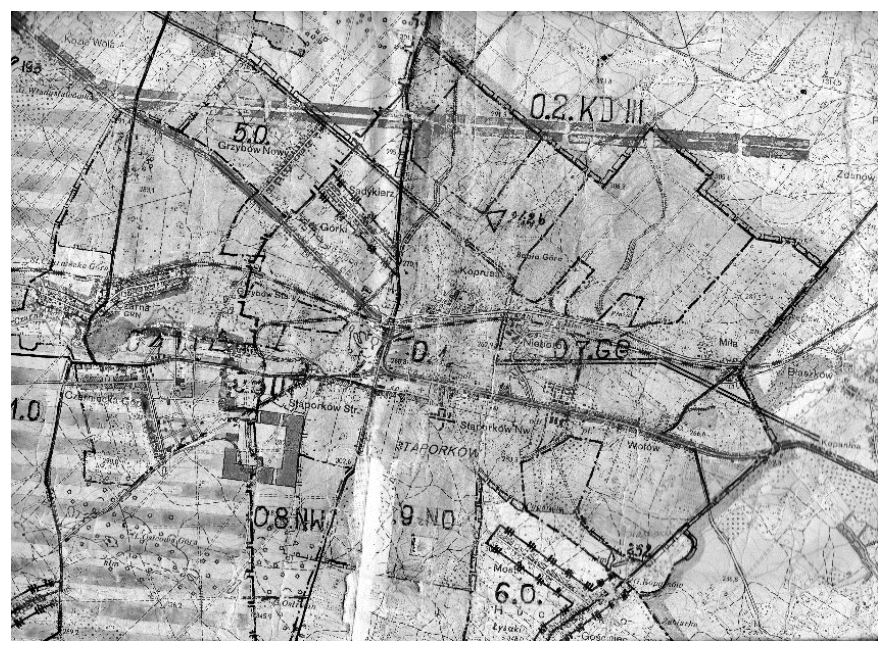

Ryc. 5. Mapa zagospodarowania przestrzennego Gminy Staporków,

C. Szumilas, J. Raczkowski, W. Zarzycka, lata 1962/3, zbiory prywatne

Tamże.

42 Tamże. 


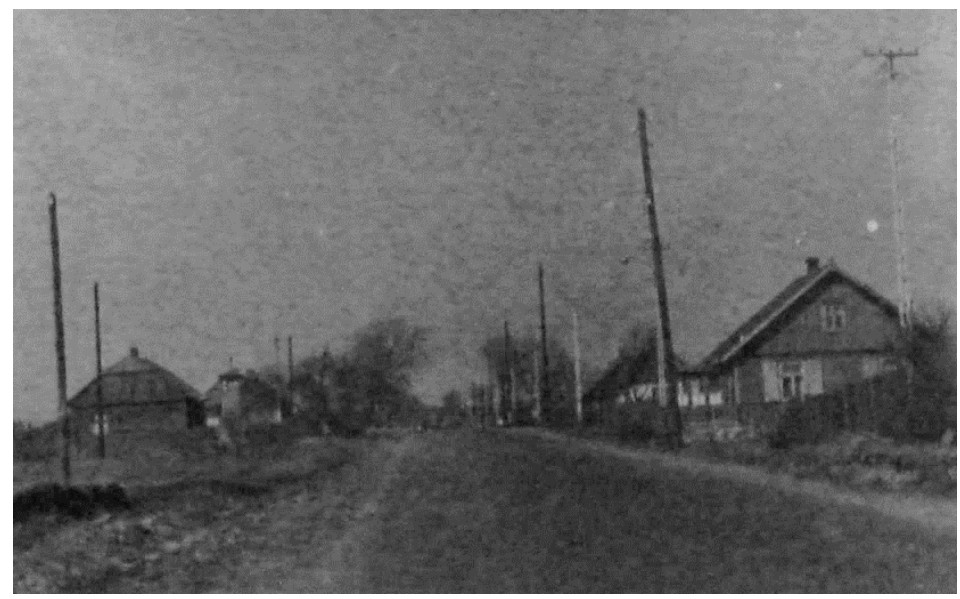

Ryc. 6. Stąporków, fot. Z. Mączyński, 1969 r., zbiory prywatne

Zakłady w Stąporkowie utrzymywały od pokoleń wiele rodzin z obszaru ziemi koneckiej. Tradycje zawodowe były podtrzymywane przez kolejne pokolenia. W 1967 r. Stąporków uzyskał prawa miejskie, a w jego herbie znajdują się elementy nawiązujące do tradycji przemysłowych. Rolniczy charakter osady w kolejnych dekadach ulegał stopniowemu zatarciu.

\section{Summary}

\section{From a Rural Settlement to an Industrial Town. History and Urban Development of Stąporków from the $18^{\text {th }}$ century to the $1960 \mathrm{~s}$.}

Urban analysis covers the period from the construction of the first blast furnace in the Konecki estates - 1738/39 until 1967 when Stąporków gained the city rights. The industrial development of the village is connected with Jan Małachowski and Jan Tarnowski. The areas around the steelworks formed the core of the "old" Stąporków developing towards the village of Czarna and the health resort of Czarniecka Góra to the west. Shortly after the Second World War, the industry was reborn in the town. Settlements for the workers of individual factories began to be built. In the 1950s, the first buildings for their employees were erected by the Iron Foundry Stąporków and the Iron Ore Mine. The constructed housing estates became the axis of the "new" Staporków focusing its spatial development around industrial plants located east of the original settlement. Between these parts, spaces of residential, functional and cultural functions appeared successively. This however, led to the lack of a clearly defined urban center of the location.

Keywords: Stąporków, city planning, industrial city, village settlement, Małachowscy, industrial factories, ironworks 


\section{Bibliografia}

\section{$\underline{\text { Archiwalia }}$}

Archiwum Akt Nowych, Osiedle Stąporków, pow. konecki [Budowa] Założenia [Decyzje, protokoły, korespondencja, notatka protokolanta], 1952-1954, sygn. 2/331/0/4.1/1870.

Archiwum Państwowe w Kielcach, Akta dóbr ziemskich hipoteki powiatu koneckiego, Końskie Wielkie 1880-1911, sygn. 19.

Archiwum Państwowe w Kielcach, Akta dóbr ziemskich hipoteki powiatu koneckiego Staporków 1909-1932 [1941], sygn. 45.

\section{Opracowania}

Anonim, Przemystowe tradycje Staporkowa (I), „Odlewnik” 1978, nr 8 (102), s. 3.

Fajkosz A., Kartki z historii ziemi koneckiej, Wydawnictwo Muzeum Regionalne PTTK, Kielce Agencja JP, Kielce-Końskie 2010.

Fajkosz A., Tradycje przemysłowe Staporkowa. Rozwój przemysłu na terenie Staporkowa i jego okolic od końca XV wieku do roku 1945, [w:] Wczoraj i dziś staporkowskich odlewni, red. A. Fajkosz, Wydawca Odlewnia Żeliwa Stąporków im. Rewolucji 1905 r., Stąporków 1978, s. 5-26.

Fajkosz A., Z kart historii: Staporków, „Tygodnik Konecki” 1997, nr 24, s. 11.

Fajkosz A., Zaczęło się od wielkiego pieca (Z historii Staporkowa), „Odlewnik” 1980, nr 6 (136), s. 4.

Osiński J., Opisanie polskich żelaza fabryk, Drukarnia J.K. Mci i Rzeczypospolitey u XX. Scholarum Piarum, Warszawa 1782.

Piwek J., Górnictwo i hutnictwo w dobrach białaczowskich Małachowskich w XIX wieku, [w:] Tradycje przemystowe ziemi koneckiej. Materiaty przygotowane na sesje naukowa Końskie 4-5 października 1991, red. W. Różański, Wydawca Towarzystwo Przyjaciół Górnictwa Hutnictwa i Przemysłu Staropolskiego w Kielcach, Zarząd Miejski Naczelnej Organizacji Technicznej w Końskich, Kielce 1991, s. 33-40.

Podrzucki C., Kalata C., Metalurgia i odlewnictwo żeliwa, Wydawnictwo Śląsk, Bytom 1971.

Radwan M., Wielkopiecownictwo w Zagtębiu Staropolskim w połowie XIX wieku, Wydawnictwo Państwowe Wydawnictwo Techniczne, Stalinogród 1954.

Różański W., Rozwój odlewnictwa żeliwnego na ziemi koneckiej, [w:] Tradycje przemysłowe ziemi koneckiej. Materiały przygotowane na sesję naukowa, Końskie, 4-5 października 1991, red. tegoż, Wydawca Towarzystwo Przyjaciół Górnictwa Hutnictwa i Przemysłu Staropolskiego w Kielcach, Zarząd Miejski Naczelnej Organizacji Technicznej w Końskich, Kielce 1991, s. 41-49.

Stownik geograficzny Królestwa Polskiego i innych krajów słowiańskich, red. F. Sulimierski, B. Chlebowski, W. Walewski, t. 4, Wydawca S. Sikorski, Warszawa 1883.

Stownik geograficzny Królestwa Polskiego i innych krajów słowiańskich, red. F. Sulimierski, B. Chlebowski, W. Walewski, t. 11, nakładem Władysława Walewskiego Warszawa 1883.

Szymański T., 250 lat staporkowskich odlewni, „Przegląd Odlewnictwa” 1989, nr 4, s. 117 121.

Wielka Encyklopedia Powszechna Ilustrowana, t. 37-38, O. Kolberg, Wydawca S. Sikorski, Warszawa 1905.

Witkowski O., W ludowej Ojczyźnie, [w:] Wczoraj $i$ dziś staporkowskich odlewni, red. A. Fajkosz, Wydawca Odlewnia Żeliwa Stąporków im. Rewolucji 1905 r., Stąporków 1978, s. 62-76. 
Wojewódzki R., Najważniejsze zabytki techniki powiatu koneckiego, [w:] Tradycje przemysłowe ziemi koneckiej. Materiały przygotowane na sesję naukowa, Końskie, 4-5 października 1991, red. W. Różański, Wydawca Towarzystwo Przyjaciół Górnictwa Hutnictwa i Przemysłu Staropolskiego w Kielcach, Zarząd Miejski Naczelnej Organizacji Technicznej w Końskich, Kielce 1991, s. 51-61.

Zawiadomienie, „Gazeta Warszawska” 1932, s. 9. 